\title{
TITLE:
}

\section{Li-ion battery recycling and cobalt flow analysis in Japan}

$\operatorname{AUTHOR}(S)$ :

Asari, Misuzu; Sakai, Shin-ichi

CITATION:

Asari, Misuzu ...[et al]. Li-ion battery recycling and cobalt flow analysis in Japan. Resources, Conservation and Recycling 2013, 81: 52-59

ISSUE DATE:

2013-12

URL:

http://hdl.handle.net/2433/179792

RIGHT:

(C) 2013 Elsevier B.V. 
Original articles

Li-ion battery recycling and cobalt flow analysis in Japan

Misuzu ASARI*, Shin-ichi SAKAI

Kyoto University Environment Preservation Research Center

*Yoshida Honmachi, Sakyo-ku, Kyoto, 606-8501

TEL: +81-75-753-7711 FAX: +81-75-753-7710

misuzuasari@eprc.kyoto-u.ac.jp

Key words

Li-ion battery, Cobalt, Questionnaire, Substance Flow analysis, Chemical analysis 


\begin{abstract}
(200)
Batteries sometimes contain precious or toxic substances (e.g. nickel, cobalt, lead, mercury, cadmium). However, the collection and recycling rate of small batteries were low in Japan.

We focus on cobalt in lithium ion (Li-ion) batteries and conduct chemical analysis, questioner survey and flow analysis in Japan.

Results of chemical analysis showed that the concentration of cobalt in Li-ion batteries was around $20 \%$ regardless of the year manufactured or the manufacturer. As a result of the consumer questionnaire survey, it became clear that $70 \%$ or more of the small batteries are not being removed when small electronic products are finally disposed. The survey also revealed that recognition of the law and system for collection and recycling of small rechargeable batteries is approximately $30-40 \%$. Substance flow analysis showed that both production and demand for $\mathrm{Li}$-ion batteries (cobalt) have increased during 2002 and 2010. The collection rate for used Li-ion batteries was about $10 \%$ during this period; uncollected batteries were either stored or disposed through incineration and landfill as municipal solid waste.
\end{abstract}




\section{Introduction}

Batteries are broadly used in home and industry, and various types are produced to accommodate the intended use. Some contain toxic and precious substances (lead, mercury, cadmium, cobalt, etc.), and the environmental impact of the disposal process has been studied (Kyle, 2010; Almeida, 2009; Hawkins, 2006; Bergback, 1994), especially as a typical example of household hazardous wastes (HHW).

In Japan, we don't have so called battery recycling law, and the framework for collection and recycling differs with the type of small (portable) battery. The 2001 Law for the Promotion of Utilization of Recyclable Resources addresses the collection and recycling by the battery manufacturer and battery apparatus manufacturer of four kinds of small rechargeable batteries: small sealed lead storage batteries, nickel-cadmium ( $\mathrm{NiCd}$ ) batteries, nickel-metal hydride (NiMH) batteries, and lithium ion (Li-ion) batteries. The aim of this law is to promote the voluntarily collection and recycling by manufacturers for products which need recycling and are recyclable. There is no legal framework covering other primary batteries, such as manganese cells and alkaline batteries, and the management system for these batteries is controlled by local governments-some municipalities landfill or incinerate, whereas others separately collect and recycle them. Although there are no legal framework covering button cells (the small flat batteries often found in small electronic devices), voluntary collection and recycling by producers started in 2009.

On the other hand, The Law for Promotion of Utilization of Recyclable Resources requires the collection and recycling of PC (as a built-in battery product) by the PC producer. This law also requires consumers to recycle the used PCs by sending them to the Recycling Center after applying to the producer of the PC or the PC 3R Promotion Association. In PC for household use made after October 2003, the collection and recycling fees are already included. As of mobile phones, the Mobile Recycle Network formed by the telecommunication carrier, sales company, and manufacturer voluntarily collects them. The Mobile Recycle Network collect used mobile phones, bodies of PHS, chargers and batteries voluntarily regardless of the brand or manufacturer, then carries out a proper disposal at the Resource-Recycling Business Operator.

Additionally, the Law for the Promotion of recycling of small used electronic equipment came into force from April 2013. The operation of this new law is expected to promote a wider range of the collection and recycling of electronic devices, as the current Japanese Law for Recycling of Specified Kinds of Home Appliances only applies to air conditioner, television, electronic refrigerator and freezer, electronic washing machine, and clothes dryer for household use. Even within the current law however, methods of the removal or management of the battery is not 
clarified for consumers.

Europe, on the other hand, has a Battery Directive that applies to all battery types, and also clearly prescribes its relationship with the WEEE. For example, it specifically guarantees to design a battery that can be easily removed, or to remove and recycle batteries that get collected together with the WEEE as it applies to the Battery Directive as well. Also, there are targets to be achieved in collection rate and recycling (recover) rate for batteries in EU, but there aren't in Japan.

SFA (substance flow analysis) are done to evaluate the effectiveness and the actual condition of battery recycling. There has been some studies for NiCd batteries focusing on Cd. SFA of Cd were conducted in Japan (Matsuno Y, 2012; Asari M, 2011; Nakanishi J, 2008), Australia (Kwonpongsagoon S , 2007), USA (Hawkins TR, 2006) and Cape Town, South Africa (Kyle, 2010), and it was found that $\mathrm{NiCd}$ battery made the dominant contribution to overall $\mathrm{Cd}$ flows in each country or region, and that enhancement of management or collection of NiCd battery is important.

There are some studies focusing on Li-ion batteries. Saskia Ziemann et al. (Ziemann S, 2012) carried out substance flow analysis of Li in the world, and showed the large contribution of Li-based batteries now and in the future. Jo Dewulf et al. (Dewulf J , 2010) described substance flow of Co and $\mathrm{Ni}$ in some lifecycle scenarios of Li-ion battery, and showed the effect of recycling in natural resource saving and energy reduction. Chang et al.(2009) conducted SFA of $\mathrm{Li}$-ion batteries focusing on $\mathrm{Li}, \mathrm{Co}, \mathrm{Al}, \mathrm{Cu}$ and $\mathrm{Ni}$ in Taiwan, and described the requirement of suitable collection, recycling and reuse procedure.

Rydh and Svard (2003) assessed the impact of the use of small rechargeable battery on global metal flows focusing on NiCd, Ni-MH and Li-based batteries. Based on this assessment, metals from disused batteries should be recovered and regulations implemented to decrease the need for mining of virgin metals.

The previous studies show that for the flow of $\mathrm{Cd}, \mathrm{Co}$ or $\mathrm{Li}$, the small batteries were the main product and that the management system including the collection and recycling was important. However, most of them are flow of a single fiscal year and only a few have showed a secular change. Moreover, not many of them targeted the battery built-in final product (small-sized consumer electronics).

The objective of this study was to investigate the flow of small rechargeable batteries in Japan to promote further discussion of future management systems. We conducted a substance flow analysis of small rechargeable batteries for a precious substance (cobalt), focusing on Li-ion batteries. The 
study focused on the period from 2002 to 2010 , as well as focused on the final product. To obtain important information for the flow analysis, we conducted an analysis on the chemical characterization of the Li-ion batteries and a consumer questionnaire.

\section{Materials and methods}

\subsection{Chemical analysis for Li-ion batteries}

In order to understand the chemical property of the Li-ion batteries, the amount of metal contained in the PC and mobile phone batteries from different manufacturer and manufactured year were measured. Table 1 shows the summary of the samples. The weight of each part was measured after the sample was dismantled and arranged into individual parts. After the sample was adjusted, it was incinerated in an electric furnace. Heating acidic digestion was taken out by adding aqua regia to the incinerated sample. Finally after filtering and fixing the volume, the metallic element was measured using ICP-AES (Shimazu, ICPS-8100) or ICP-MS (VARIAN, 820-MS).

\subsection{Consumer questionnaire for end-of-life Li-ion batteries}

The consumer questionnaire survey was carried out through the Internet. This survey focused on the small rechargeable batteries including Li-ion batteries. The scheme of study is shown in Table 2.

\subsection{Life-cycle flow analysis of Cobalt focusing on Li-ion batteries}

Focusing on products containing Co in Japan, we analyzed the annual life-cycle flow and stock of Co between 2002 and 2010. Substance flow of Co in Japan has been reported by Japan Oil, Gas, and Metals National Corporation (JOGMEC) every year (JOGMEC, 2011). However, this study takes into account only the substance flow of Co related to an intermediate product, i.e., the Li-ion batteries that are built into final products. In this analysis, we include not only products with built-in Li-ion batteries but also end-of -life products, the imports to Japan, and the exports from Japan.

The life cycle of products was divided into four stages: 1. raw material, 2. intermediate products (batteries), 3. final products (products with built-in Li-ion batteries), and 4. end-of-life products. Factors of input, output, and stock for the main products at each stage were estimated on the basis of statistical data, date from chemical analysis and questionnaire survey in this study, and estimates.

For the raw-material stage of Co, statistics for steel, nonferrous metals, and metal-goods (METI, 2011a) were the primary sources of data. Additionally, foreign trade statistics (MOF, 2011) were used for the export and import amounts, and machine statistics (METI, 2011b) were used to determine the amount of total demand allocated to rechargeable batteries ( $\mathrm{Li}$-ion and $\mathrm{Ni}-\mathrm{MH}$ 
batteries).

Both intermediate and final products were included in import and export data in the foreign trade statistics (MOF, 2011), as well in production, sales, and stock amount data in the machine statistics (METI, 2011b). The Co concentration, used to make a conversion to the amount of Co, was taken from the result of analysis of this study (Table 4) which means the average for notebook PCs (16\%), mobile phones (23\%), average for both $(19.6 \%)$ were used. For the final product, mobile phone that uses Li-ion batteries, notebook PCs, digital cameras, videos, electric tools, the batteries itself, and other products were applied, of which the distributed amount of the batteries itself and other products was set to $13 \%$ statistics (MOE, 2010) of the total. Out of the final product, the ratio of products that adopts Li-ion batteries, are believed to be $100 \%$ for notebook PCs and mobile phones.

For the remainders, the result of the questionnaire survey (Table 5) was used. For end-of-life products stage, we assumed that the annual amounts of domestic sales and discharge were equal. That is, all consumers are assumed to buy new products (whether domestically produced or imported) to replace old products no longer in use. First, for all products, used final products move on to either disposal or dead storage route. The ratio of disposal and dead storage is established as Table 3.

More than one disposal route was considered for each product group (Fig. 1). As for mobile phones, it proceeds to the removal of battery, collection for recycling, or MSW disposal (incineration and/or landfill) after being thrown away, according to the results from questionnaire survey. Batteries inside the mobile phones (with them remaining inside) that were handed over to recycle shops, recovery operators (private collector for reuse and recycle), friends or acquaintances, were to be taken to the Mobile Recycle Network. The batteries removed when disposing the product will proceed to storage, collection for recycling, or MSW disposal, based on the questionnaire survey. At this moment in time, we supposed that the collection of the removed batteries by both base collection and separately collection by local government are passed on to the Mobile Recycle Network.

Notebook PCs proceed to battery removal, collection for recycling, or MWS disposal, according to the actual value and the results from questionnaire survey. The actual value indicates the collection by the PC3R Promotion Association (PC3R, 2011), which in the questionnaire survey was considered as part of the PC that had batteries remaining inside them when being returned to the retail store. The removed batteries proceed to storage, collection for recycling, or MSW disposal, based on the questionnaire survey. As for removed batteries, we supposed that the ones that went through the separately collection by local government were to be passed to the collection by the Japan Portable Rechargeable Battery Recycling Center (JBRC). 
For the others (general products), it proceeds to battery removal, collection for recycling, or MSW disposal after being thrown away, based on the questionnaire survey. The removed batteries proceed to storage, collection for recycling, or MSW disposal, based on the questionnaire survey. We supposed that the ones that went through the separately collection for recycling by local government were all to be passed to the collection by the JBRC.

\section{Results and discussion}

\subsection{Chemical analysis for Li-ion batteries}

The result of the analysis of the metal contained in the Li-ion batteries and previous research results (Oguchi M , 2004; Defra, 2006) are shown in Table 4. This shows that, Li-ion batteries contain a lot of $\mathrm{Li}, \mathrm{Co}, \mathrm{Ni}$, and $\mathrm{Cu}$ and also contain $\mathrm{Mn}, \mathrm{Au}$, and $\mathrm{Pb}$. As for $\mathrm{Co}$, the table demonstrates that notebook PCs had a concentration of 4\%-26\% showing a one digit gap, whereas mobile phones had a concentration of approximately $20 \%$, regardless of the manufacturer or manufactured year. This was identical to the preexisting research results. The concentration for Co should be considered along with its future product development trend in mind.

\subsection{Consumer questionnaire for end-of-life Li-ion batteries}

Table 5 shows the result of asking the kind of battery they had to people who owned a final product with batteries inside. This demonstrates the possibility that Li-ion batteries were used in more than half of cameras. As all current notebook PCs and mobile phones are considered to be using Li-ion batteries, it was not included in the questionnaire.

Figure 2 shows the result of the question that asked the method used to dispose small consumer electronics. This demonstrates that, digital cameras, video cameras, and cordless electric tools have similar tendency. The discharge of incombustible waste and oversized waste by the local government, and the collection by the retail store are 20-30\% each being the main route. As for mobile phones, tablet terminators, and notebook PCs, the ratio of collection by the retail shops is relatively high being $30-50 \%$. However, at the same time the ratio of notebook PCs being handed over to recovery operators are approximately $20 \%$.

For all products, the ratio of them being discharged as combustible waste or incombustible waste by the local government are, $40-50 \%$ for electric tools, approximately $30 \%$ for digital cameras and video cameras, $10-20 \%$ for mobile phones, tablet terminators, and notebook PCs.

The result of the question asking whether battery removal was taken place when disposing small 
electronics is shown in Figure 3. This shows that the ratio of battery removal taking place is $10-30 \%$ and others discharged them without battery removal. The majority of the reasons not removing the batteries were because they either "did not think it was necessary" or "did not even think about it". This proves the necessity of clearly mapping out where small batteries should go when discharging or recovering small electronics, and earning a wider recognition.

The results of the question asking the method of disposal used for small batteries are shown in Figure 4. We considered Li-ion batteries as part of the rechargeable batteries. Batteries that were not removed from the small consumer electronics are not included in this question. The result shows that the ratio of them being discharged by the local government as combustible waste, incombustible waste, or oversized waste is a little more than $30-40 \%$.

As for small batteries, the result of the question about the degree of recognition of the law or system (by the manufacturer) regarding collection and recycle is shown in Figure5. This shows that the degree of recognition is about $30-40 \%$.

These results show that small batteries tend to be discharged while remaining inside of small consumer electronics and that the ratio of the possibility of them being disposed through incineration or landfill is about $10-40 \%$. Possibly $40 \%$ of the batteries that were removed were also disposed through incineration or landfill. The fundamental issues regarding this result are the provision of information and the degree of recognition.

\subsection{Life-cycle flow analysis of Cobalt focusing on $\mathrm{Li}$-ion batteries}

Figures 6 and 7 show the flow of Co in Japan in 2002 and 2010, respectively. Most domestic Co flows are associated with Li-ion batteries and products with built-in Li-ion batteries. Most of the material $\mathrm{Co}$ for $\mathrm{Li}$-ion batteries was imported. Moreover, most $\mathrm{Li}$-ion batteries produced domestically were exported as intermediate products. Domestically-produced final products with built-in Li-ion batteries were mainly sold domestically. Almost half of end-of-life products were stored, and the remainder were collected in almost equal amounts for disposal such as incineration or landfill.

At the raw-material stage, demand for Li-ion batteries expanded from 3500 to $8000 \mathrm{t}$-Co during the study period. The demand for Co for NiMH batteries also increased from 480 to 950 t-Co. These results reflect the shift in the types of rechargeable batteries used during this period.

The amount of exported Co also more than doubled, from 1600 to $4100 \mathrm{t}$-Co, most likely because of increased demand from Japanese-owned Li-ion battery factories in China and other countries. In 
recent years, Sony and Panasonic, which are the main Li-ion battery producers in the world, have announced plans to relocate the production base of $\mathrm{Li}$-ion batteries to China, and the export volume of Co is likely to continue increasing.

In Figures 6 and 7, only the Co flow related to Li-ion batteries is shown at the intermediate and final stages. There was a great expansion in both the domestic demand for and exports of Li-ion batteries. Exports of Li-ion batteries in 2010 totalled 7900 t-Co, accounting for about $90 \%$ of total domestic production. From 2002 to 2010, end-of-life products with built-in Li-ion batteries also increased from 670 to $1100 \mathrm{t}$-Co.

Figure 8 shows the domestic sales of products with built-in Li-ion batteries. Overall, Co flow in 2010 was about 1.5 times that in 2002. The contribution of notebook PCs, which have comparatively large batteries, was the largest. The market for notebook PCs expanded because of improvements in the computers during the study period, and domestic sales increased to the point that Li-ion batteries for notebook PCs represented more than half of the total demand (570 of $1050 \mathrm{t}-\mathrm{Co}$ ) in 2010.

The percentage of collection for recycling of the Li-ion batteries calculated from the disposal amount against the collection amount was approximately $10 \%$. Figure 9 show the products which the batteries recovered come from and Figure 10 shows what kind of disposal route each batteries from final product followed. Most of the sold products were notebook PCs but mobile phones and notebook PCs were at the same level regarding its collection for recycling. This demonstrates the possibility that there are a large number of products that get stocked in total, and the high possibility of notebook PCs being reused. It can be argued that understanding the actual situation of the collection of dead storage products or products that are reused will become critical in the future. Here, the estimated value of collection amount of mobile phone and actual value reported by Mobile Recycle Network (JBRC, 2011) were practically the same.

Comparing to NiCd battery and cadmium flows in Japan (Asari M, 2011), most domestic Cd flows are associated with $\mathrm{NiCd}$ batteries like $\mathrm{Co}$ in Li-ion batteries. A common feature of both flows was that a large portion of batteries produced domestically were exported. The $\mathrm{Cd}$ flow decreased notably during these years, coinciding with reduced use of $\mathrm{NiCd}$ batteries domestically and production shifts to China and other countries. Conversely, the flow of Co increased as the use of Li-ion batteries increased.

Comparing to Li battery flow in Taiwan (Chang TC, 2009), Taiwan imports more Li batteries than domestic production, through Japan is a world producer of Li-ion batteries and export most of batteries produced domestically. A common feature was that a large portion of batteries was still in use, stored at home or industry and collection and recycling or proper management is desired. 
Considering collected Li-ion batteries in Japan, they are recycled at some domestic recycling facilities. They are treated with heat, and mix metal of $\mathrm{Co}, \mathrm{Fe}, \mathrm{Al}$ and $\mathrm{Cu}$ is recovered now. In addition, there are several technologies for recycle and recovery (Zhang X, 2013). For example, commercial scale hydrometallurgical process showed good results and capability to recover Co and $\mathrm{Ni}, \mathrm{Mn}, \mathrm{Li}$ from cathode materials (Yamaguchi Y, 2011). On the other hand, for others which are disposed as MWS (incineration and/or landfill) or stored at houses, there are not only lack of recourse recovery but also risks including fire, explosiveness and toxicity (Chang TC, 2009). So, a radical discussion over battery management including Li-ion battery will be required in Japan. Based on our results, suitable design or labeling for easy removal of battery from final products, information exchange regarding the removal and collection of battery between producers, consumer and government, development of effective collection and recycle system are suggested to be important.

\section{Conclusion}

In this study, we investigated Li-ion batteries and the final product that contains these batteries, through chemical property research, consumer questionnaire, and flow analysis. The result from the chemical property research showed the importance in collection and recycling the $\mathrm{Li}$-ion batteries as it contained approximately $20 \%$ of $\mathrm{Co}$, and other various kinds of metal.

The result from the consumer questionnaire survey demonstrated the tendency of small consumer electronics being discharged with small batteries remaining inside them, and suggested the fact that since the information regarding the collection for recycling of small batteries is not widely recognized, the collection of these batteries will only show little progress. It can be said that in Japan, even though the collection and recycle of small consumer electronics will progress in the future, it will yet need to establish a clearer guideline for battery removal and maintenance, and a wider recognition by both the manufacturer and consumer.

From the substance flow analysis of Co centering the Li-ion batteries, became clear that between 2002 and 2010, the amount of flow is expanding in response to the demand of Li-ion batteries of mainly notebook PCs and mobile phones. On the other hand, the collection rate for recycling of the Li-ion batteries is sluggish being approximately $10 \%$, showing the necessity of develop a better collection and recycle system.

It can be argued that number of Li-ion batteries will increase dramatically in the future in response to the spread of electric cars. The small $\mathrm{Li}$-ion batteries are currently considered to be having different battery weight and Co concentration, and the examination of its battery development trend 
or collection and recycling system and technology also requires high caution.

Additionally, keeping in mind that there will be various types of batteries developed and spread in the future, a radical discussion over battery management will be required in Japan.

\section{References}

Almeida MF, Xara SM, Delgado J, Costa CA. Laboratory study on the behavior of spent AA household alkaline batteries in incineration. Waste Management 2009; 29 (1): 342-9

Asari M, Sakai S. Consumer perspectives on household hazardous waste management in Japan. Journal of Material Cycles and Waste Management 2011; 13: 10-24

Bergback B, Anderberg S, Lohm U. Accumulated environmental impact -the case of cadmium in Sweden. Science of the Total Environment 1994; 145 (1-2): 13-28

Chang TC, You SJ, Yu BS, Yao KF. A material flow of lithium batteries in Taiwan. Journal of Hazardous Materials 2009; 163 (2-3): 910-5

Defra. Battery Waste Management Lifecycle Assessment 2006. Department for Environment Food and Rural Affairs. Available from : http://www.epbaeurope.net/0906072006 Oct.pdf [Internet]

Dewulf J, van der Vorst G, Denturck K, van Langenhove H, Ghyoot W, Tytgat J, Vandeputte K. Recycling rechargeable lithium ion batteries; Critical analysis of natural resource savings. Resources, conservation and Recycling 2010; 54 (4): 229-34

Hawkins TR, Scott Matthewa H, Hendrickson C. Closing the Loop on Cadmium; An Assessment of the Material Cycle of Cadmium in the U.S.. International Journal of Life Cycle Assessment 2006; 11(1): 38-48

JBRC. Recycling of small rechargeable batteries 2010. Japan Portable Rechargeable Battery Recycling Center. Available from : http://www.jbrc.net/hp/contents/recycle/index.html [Internet] [in Japanese]

JOGMEC. Material flow research of Co in Japan 2011. Japan Oil, Gas, and Metals National Corporation. Available from: http://mric.jogmec.go.jp/public/report/2012-05/13.Co_20120619.pdf [Internet] [in Japanese]

Kyle MJ, Harro von Blottnitz. Flows and fates of nickel-cadmium batteries in the City of Cape Town. Minerals Engineering 2010; 23 (3): 211-8

Kwonpongsagoon S, Bader H-P, Scheidegger R. Modelling cadmium flows in Australia on the basis of a substance flow analysis. Clean Technologies and Environmental Policy 2007; 9: 313-23

Matsuno Y, Hur T, Fthenakis V. Dynamic modeling of cadmium substance flow with zinc and steel demand in Japan. Resources, Conservation and Recycling 2012; 61: 83-90

METI. Trade and Industry Japan 2011a-Statistics for steel, nonferrous metals, and metal-goods. Ministry of Economy, Trade and Industry Japan [in Japanese] 
METI. Trade and Industry Japan 2011b -Machine statistics. Ministry of Economy, Trade and Industry Japan [in Japanese]

MOE. Report on promotion of reusing end-of-life products 2010. Ministry of the Environment Japan [in Japanese]

MOF. Trade statistics 2011. Ministry of Finance Japan [in Japanese]

Nakanishi J, Ono K, Gamo M, Miyamoto K. Cd, Tokyo: Maruzen; 2008 [in Japanese]

Oguchi M, Tasaki T, Kameya T, Urano K. Evaluation of the resource consumption and water pollution potential of metals caused by disposal of portable batteries in Japan. Environmental Science 2004; 17 (6): 419-29

PC3R Promotion Association. Collection and recycling of household PC 2010. Available from : http://www.pc3r.jp/topics/130412_2.html [Internet] [in Japanese]

Rydh CJ, Svard B. Impact on global metal flows arising from the use of portable rechargeable batteries. The Science of the Total Environment 2003; 302: 167-84

Yamaguchi Y, Yoshimi T, Miyabayashi Y. Manganese, Cobalt, Nickel and Lithium Recover from Waste Lithium-Ion Batteries by Hydrometallurgical Process. The 11th International Symposium on East Asia Resources Recycling Technology 2011; 178-181

Zhang X, Xie Y, Lin X, Li H, Cao H. An overview on the processes and technologies for recycling cathodic active materials from spent lithium-ion batteries. Journal of Material Cycles and Waste Management 2013; online first

Ziemann S, Weil M, Schebek L. Tracing the fate of lithium -The development of a material flow model. Resources, Conservation and Recycling 2012; 63: 26-34

\section{Captions of Figures and tables}

Fig.1 Estimated flow of end-of-life batteries

Fig 2. The disposal route of small consumer electronics

Fig 3. Battery removal from end-of-life small electronics

Fig 4. Disposal route of end-of-life small batteries

Fig 5. Recognition of the law or system regarding collection and recycle of batteries

Figure 6. Co flow in Japan in 2002 (t-Co/year)

Figure 7. Co flow in Japan in 2010 (t-Co/year)

Fig. 8 The domestic sales of products with built-in Li-ion batteries (t-Co/year)

Figure 9. Collected batteries from each final product in 2010 (Total 99 t-Co)

Figure 10. Disposal route of batteries from each final product

Table 1. Li-ion battery samples for chemical analysis 
Table 2. Outline of questionnaire survey

Table 3. The ratio of disposal and dead storage of end-of-life products

Table 4. Results of the metal contained in the Li-ion batteries and referenced data $(\mathrm{mg} / \mathrm{kg})$

Table 5. The ratio of final products which use Li-ion battery as batteries inside 

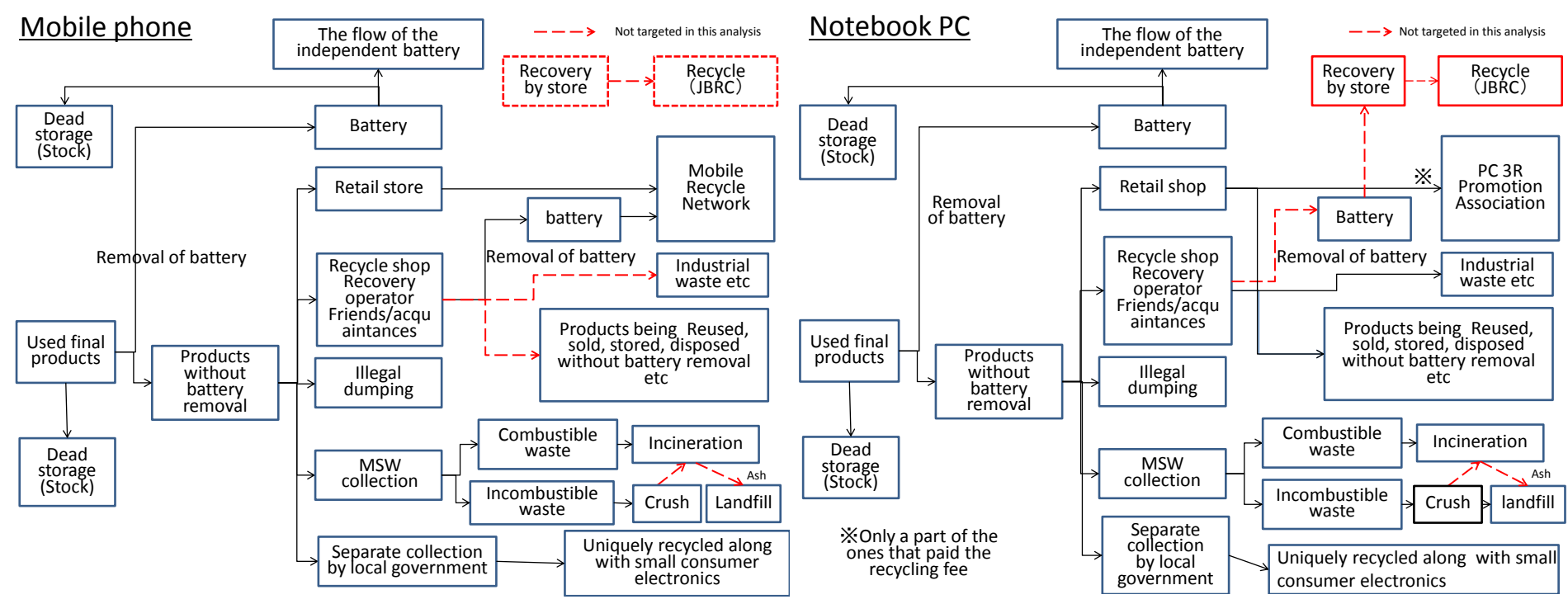

\section{General products
(except cell prones and P(s)}

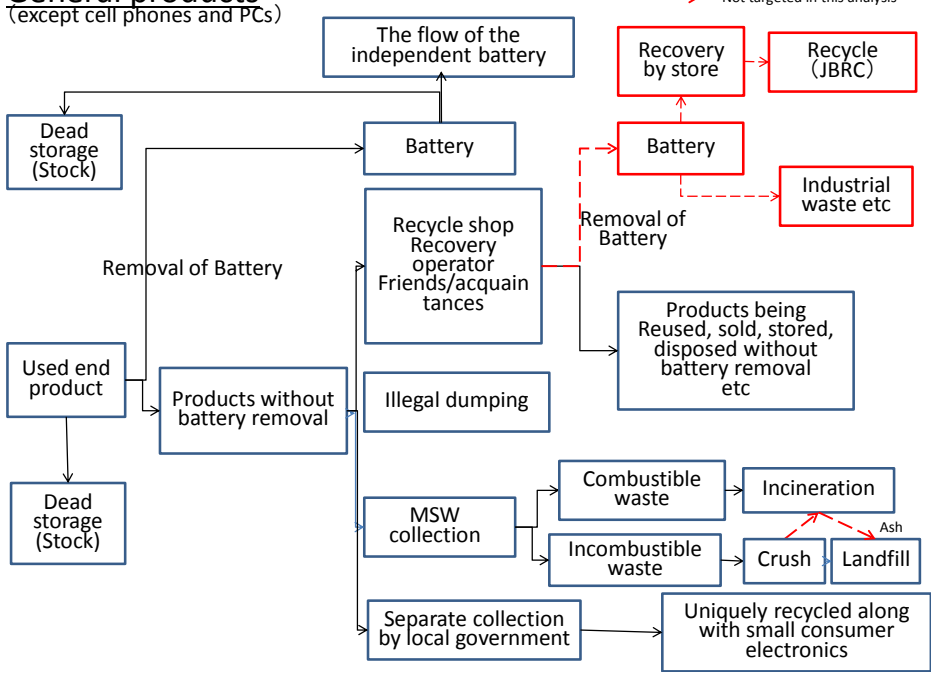

The battery

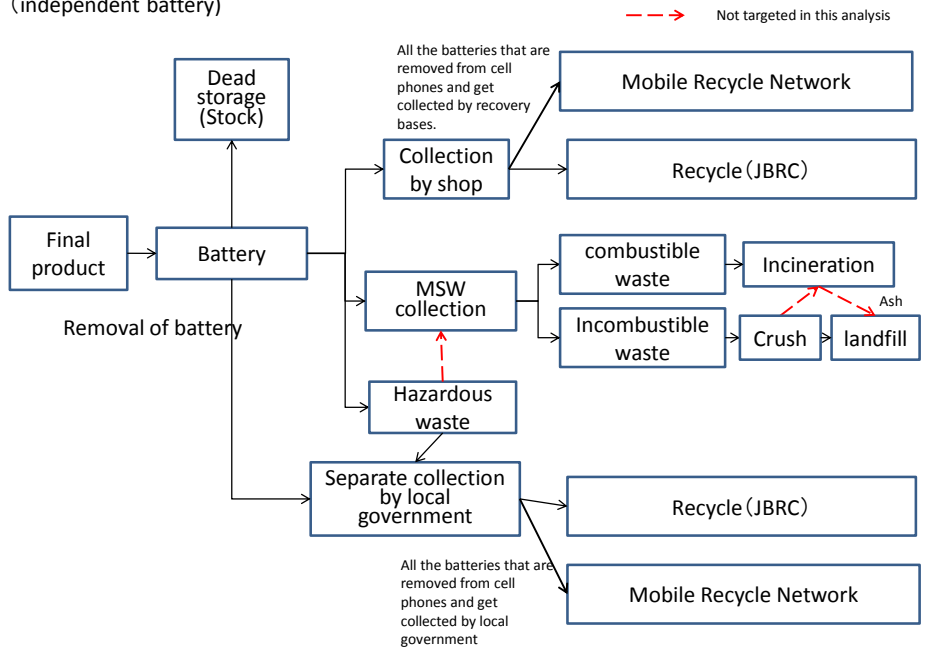

Fig.1 Estimated flow of end-of-life batteries 


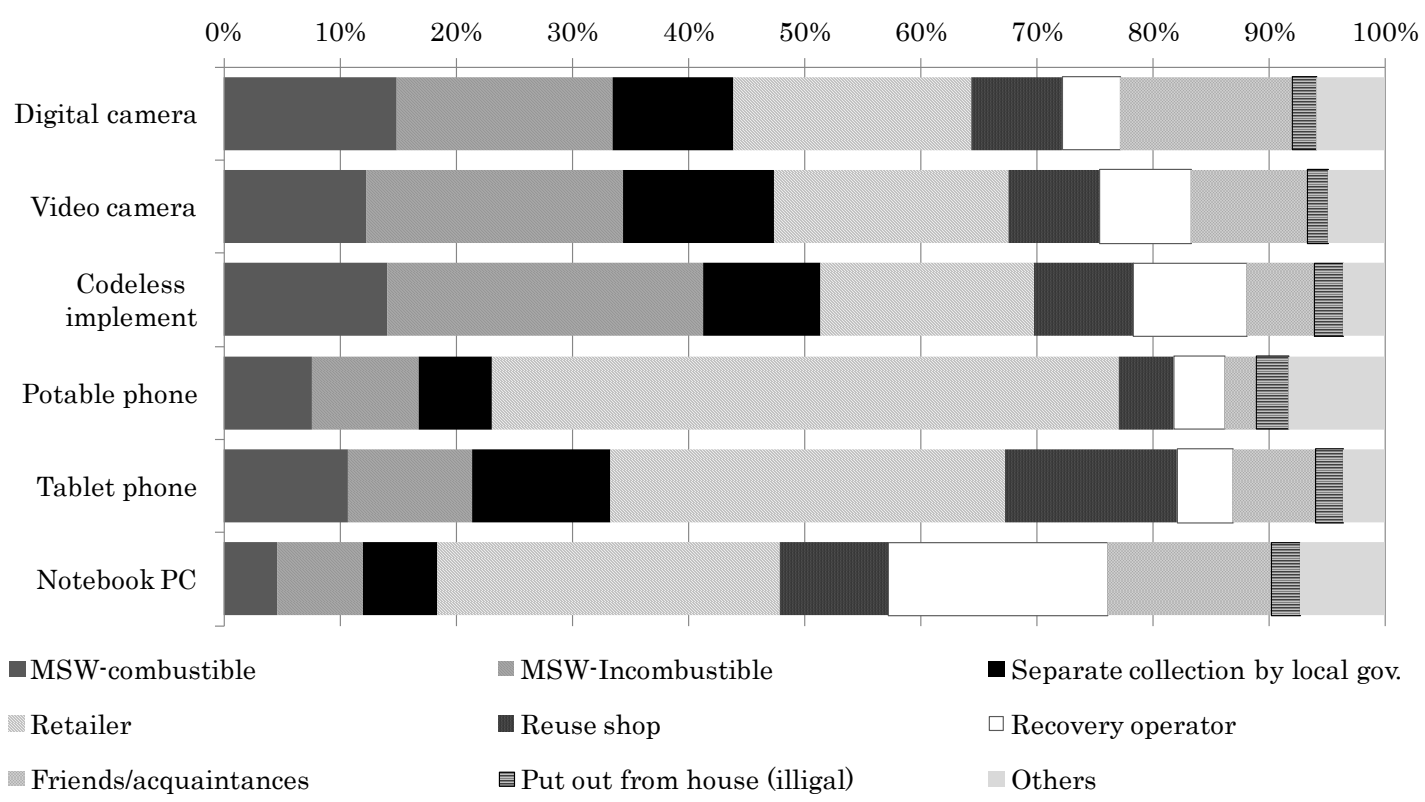

Fig 2. The disposal route of small consumer electronics 


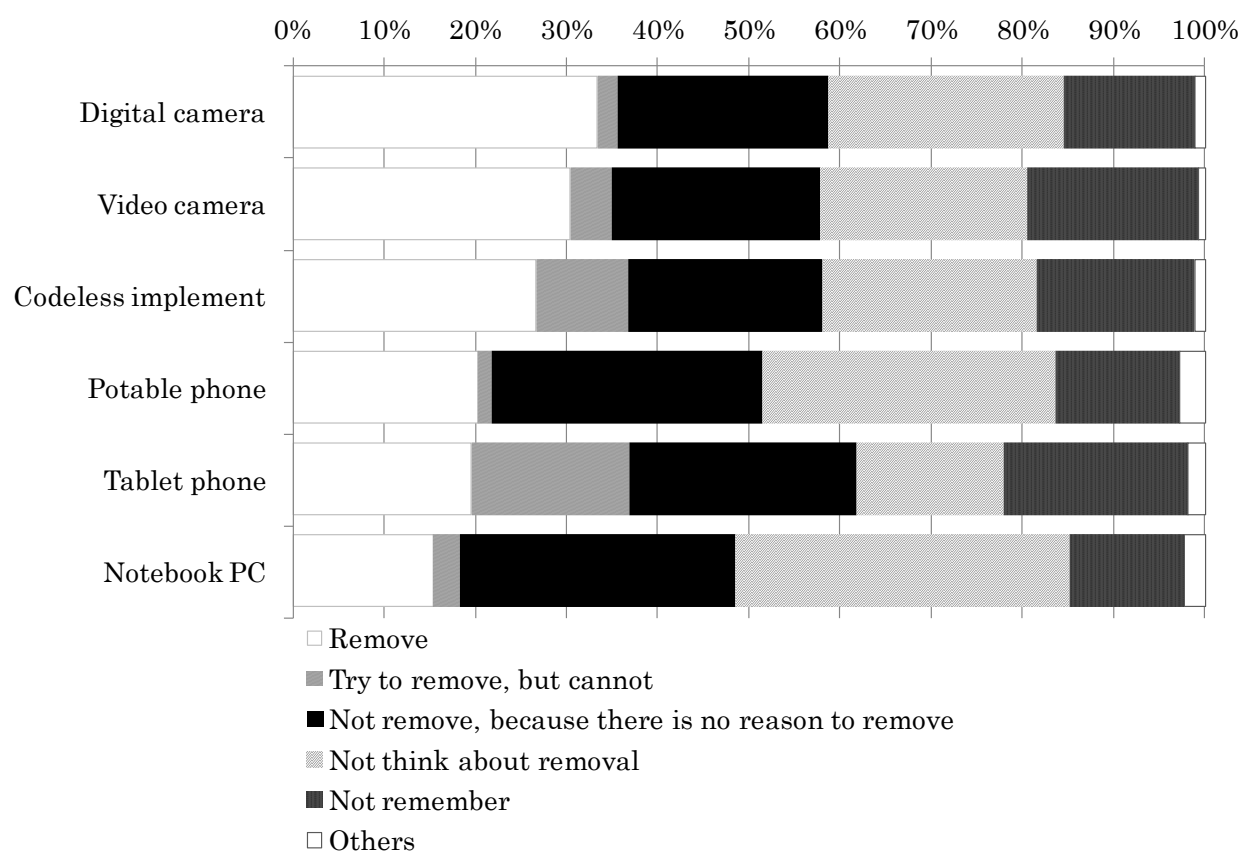

Fig 3. Battery removal from end-of-life small electronics 


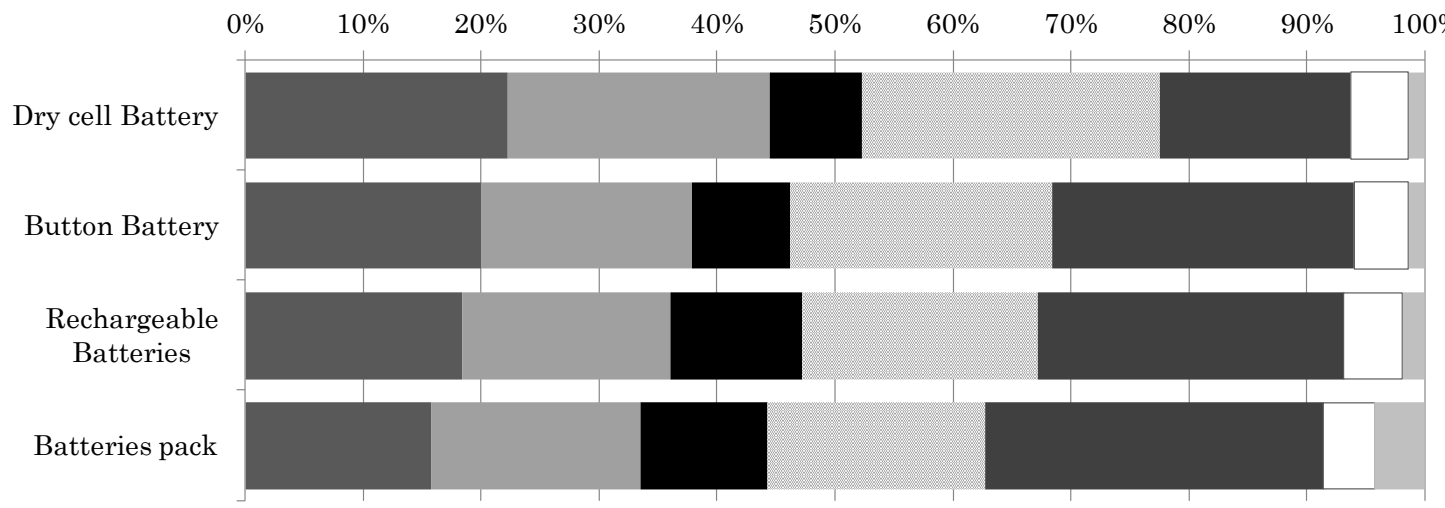

MSW-combustible

- Separate collection by local gov. as small appliances

netailer

Others
MSW-Incombustible

Separate collection by local gov. as HHW

$\square$ Collection at public place

Fig 4. Disposal route of end-of-life small batteries 


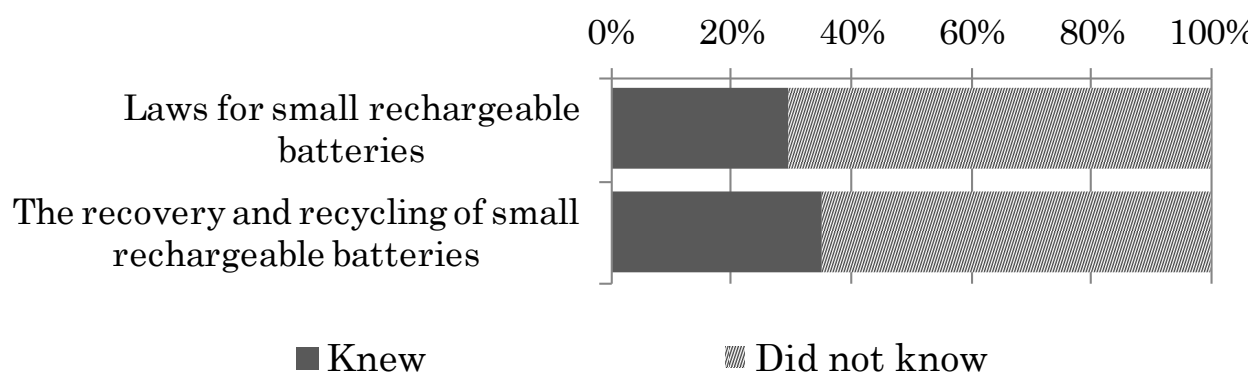

Fig 5. Recognition of the law or system regarding collection and recycle of batteries 


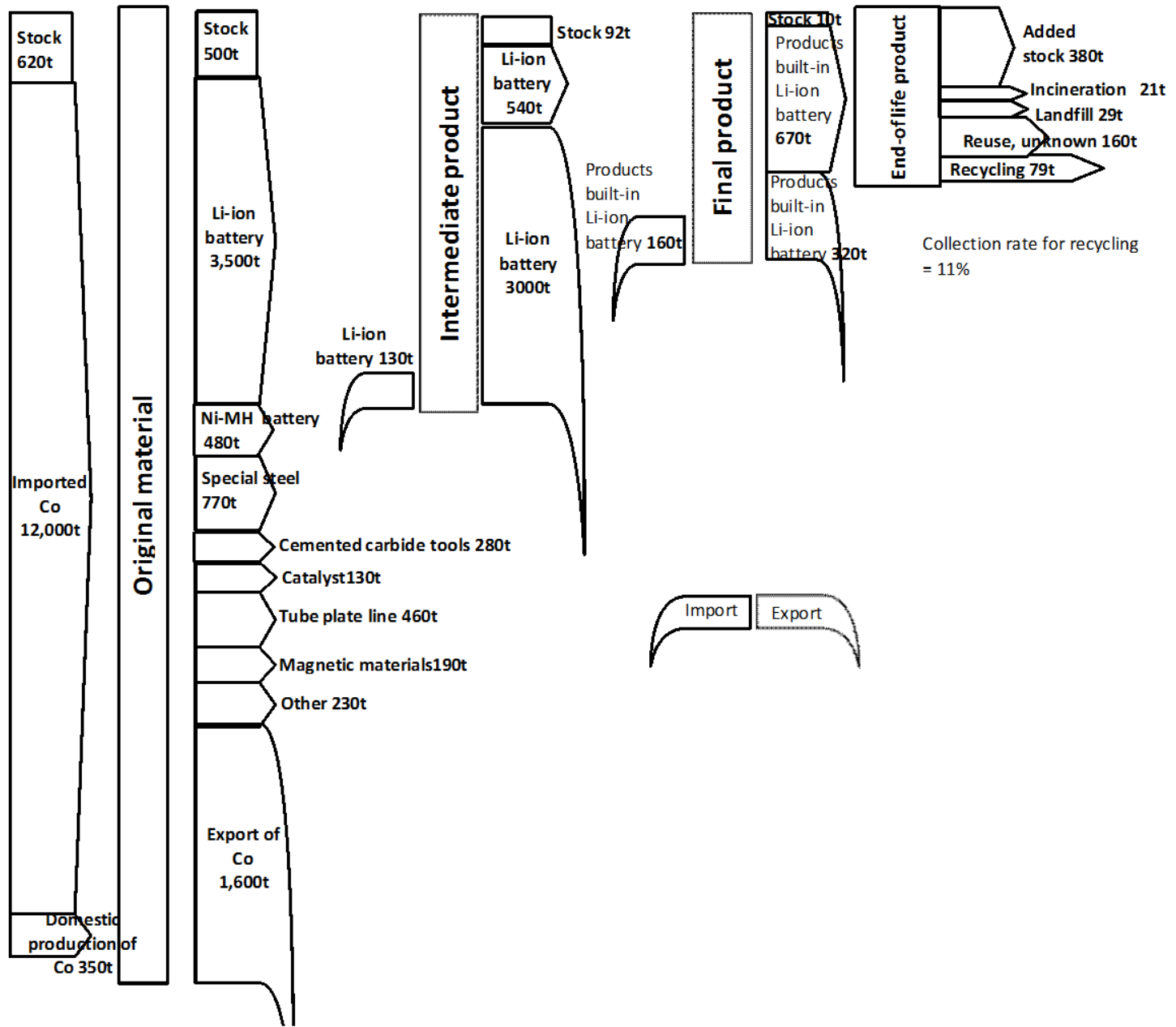

Figure 6. Co flow in Japan in 2002 (t-Co/year) 


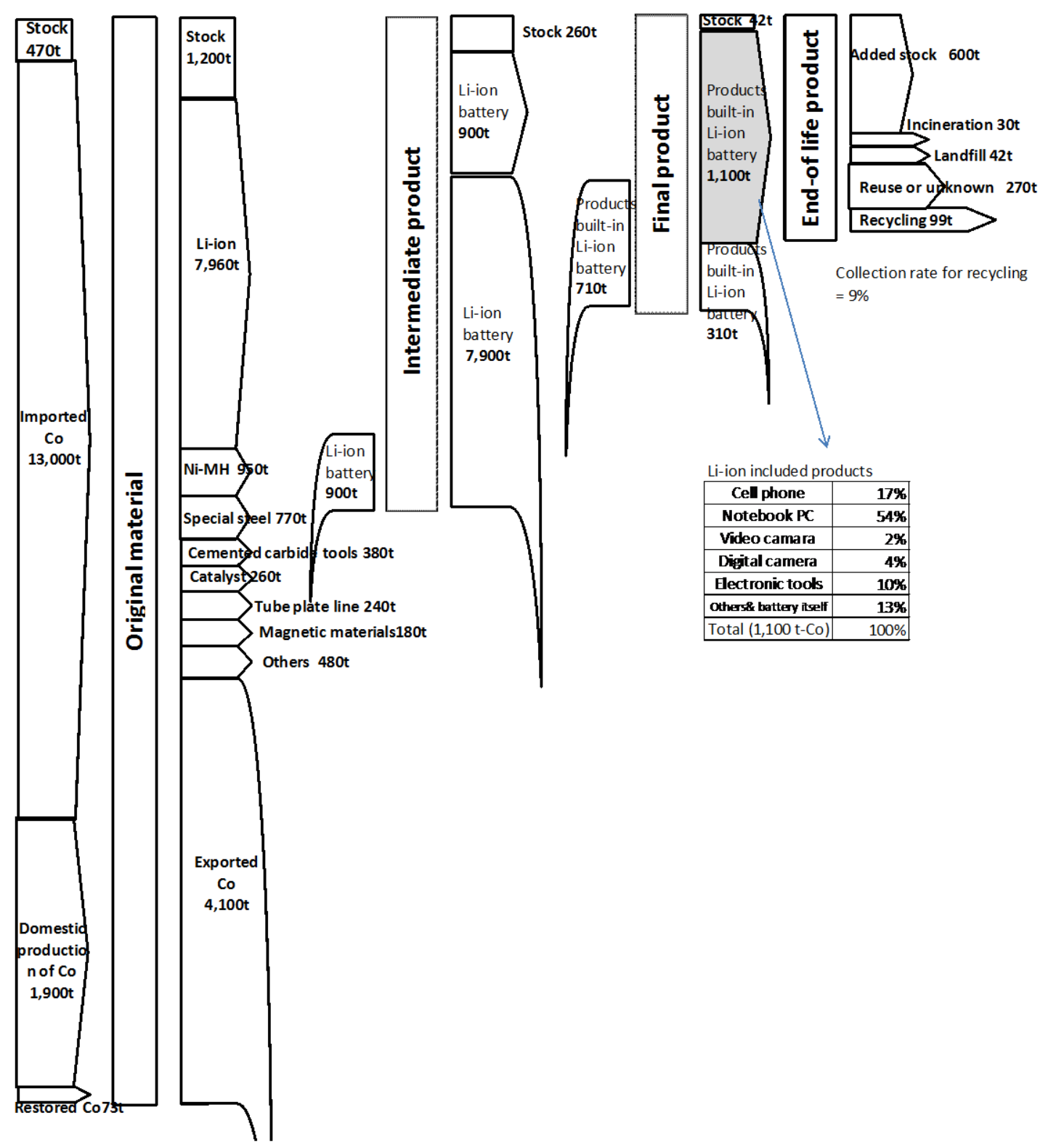

Figure 7. Co flow in Japan in 2010 (t-Co/year) 


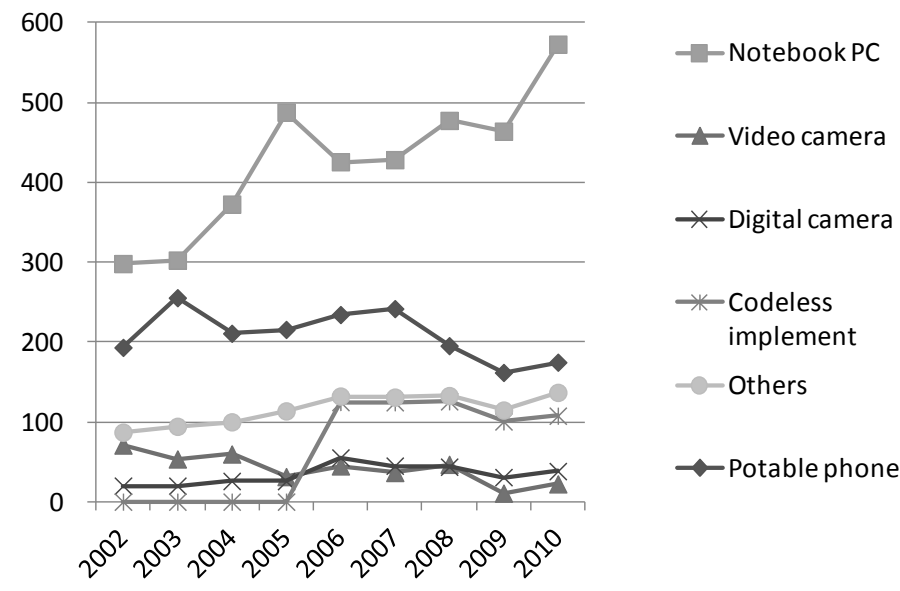

Fig. 8 The domestic sales of products with built-in Li-ion batteries (t-Co/year) 


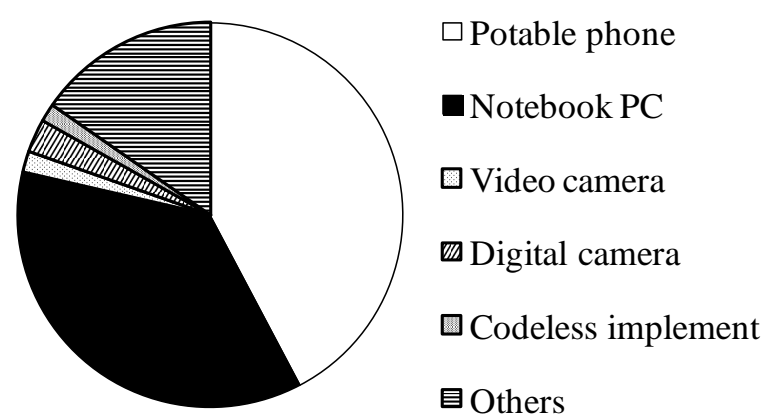

Figure 9. Collected batteries from each final products in 2010 (total 99 t-Co) 


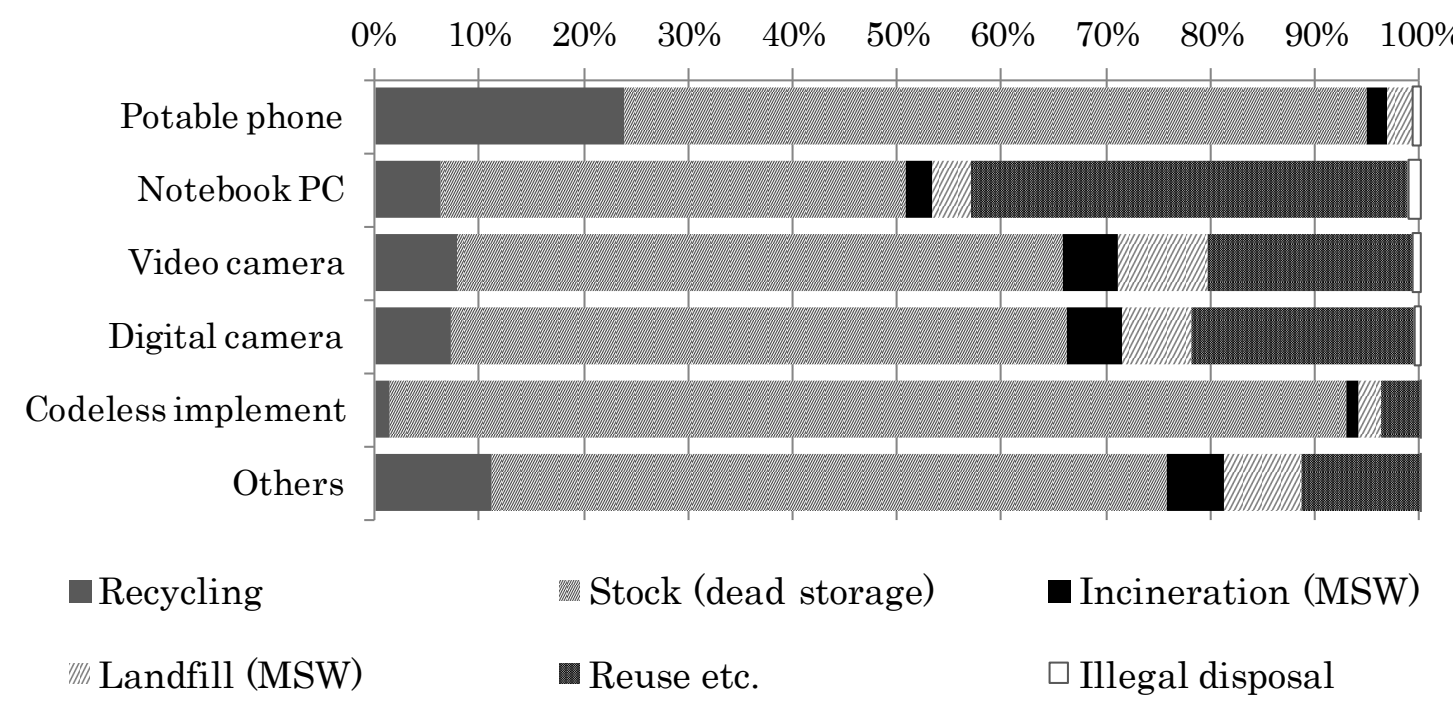

Figure 10. Disposal route of batteries from each final product 
Table 1. Li-ion battery samples for chemical analysis

\begin{tabular}{|c|c|c|c|c|c|}
\hline No & & & Producer* & Weight (g) & $\begin{array}{c}\text { Year of } \\
\text { manufacture }\end{array}$ \\
\hline L1 & \multirow{4}{*}{$\begin{array}{l}\text { Li-ion battery for } \\
\text { note book PC }\end{array}$} & \multirow{3}{*}{ New product } & A & 45.9 & 2011 \\
\hline L2 & & & B & 44.6 & 2011 \\
\hline L3 & & & $\mathrm{C}$ & 44.0 & 2011 \\
\hline $\mathrm{L} 4$ & & Used product & $\mathrm{D}$ & 19.6 & 2001 \\
\hline LP1 & \multirow{17}{*}{$\begin{array}{l}\text { Li-ion battery for } \\
\text { mobile phone }\end{array}$} & \multirow{17}{*}{ Used product } & \multirow{5}{*}{$\mathrm{E}$} & 18.8 & 2001 \\
\hline LP2 & & & & 18.2 & 2002 \\
\hline LP3 & & & & 16.6 & 2003 \\
\hline LP4 & & & & 16.6 & 2006 \\
\hline LP5 & & & & 17.7 & 2007 \\
\hline LP6 & & & \multirow{5}{*}{$\mathrm{C}$} & 16.9 & 2003 \\
\hline LP7 & & & & 17.3 & 2004 \\
\hline LP8 & & & & 17.6 & 2005 \\
\hline LP9 & & & & 18.9 & 2007 \\
\hline LP10 & & & & 18.8 & 2008 \\
\hline LP11 & & & \multirow{3}{*}{$\mathrm{F}$} & 15.7 & 2006 \\
\hline LP12 & & & & 16.6 & 2007 \\
\hline LP13 & & & & 19.4 & 2008 \\
\hline LP14 & & & \multirow{3}{*}{$\mathrm{D}$} & 16.5 & 2001 \\
\hline LP15 & & & & 17.6 & 2003 \\
\hline LP16 & & & & 17.4 & 2004 \\
\hline LP17 & & & $\mathrm{G}$ & 16.5 & 2001 \\
\hline
\end{tabular}

*Producer of notebook PC or mobile phone 
Table 2. Outline of questionnaire survey

\begin{tabular}{|l|l|}
\hline Purpose & \multicolumn{1}{c|}{ Outline } \\
\hline Date & $\begin{array}{l}\text { To grasp the consumer behavior of used small batteries and products with a } \\
\text { built-in small batteries }\end{array}$ \\
\hline Method & March 13 ${ }^{\text {th }}-19^{\text {th }}, 2012$ \\
\hline Targeted age & Internet system \\
\hline Sample number & Equally from twenties, 30's, 40's, 50's and 60's \\
\hline Targeted products & $\begin{array}{l}\text { Totally 6,500 (Japanese) } \\
\bullet \text { Small batteries including Li-ion batteries } \\
\bullet \text { Products with a built-in small batteries including digital camera, video camera, } \\
\text { cordless electric implement, mobile phone, notebook PC }\end{array}$ \\
\hline
\end{tabular}


Table 3. The ratio of disposal and dead storage of end-of-life products

\begin{tabular}{|c|c|c|c|}
\hline & $\begin{array}{l}\text { The ratio of } \\
\text { disposal }\end{array}$ & $\begin{array}{l}\text { The ratio of } \\
\text { dead storage }\end{array}$ & Estimation methods \\
\hline Mobile phone & $33 \%$ & $67 \%$ & \multirow{3}{*}{$\begin{array}{l}\text { Questionnaire by Japanese } \\
\text { Ministry of the Environment } \\
\text { (MOE, 2010) }\end{array}$} \\
\hline Notebook PC & $61 \%$ & $39 \%$ & \\
\hline Digital camera & $51 \%$ & $49 \%$ & \\
\hline Video camera & $51 \%$ & $49 \%$ & $\begin{array}{l}\text { Using the value of digital } \\
\text { camera }\end{array}$ \\
\hline Cordless electric implement & $10 \%$ & $90 \%$ & $\begin{array}{l}\text { Previous survey (Asari M, } \\
\text { 2011) }\end{array}$ \\
\hline Other final products using Li-ion & $41 \%$ & $59 \%$ & $\begin{array}{l}\text { The average value of above } \\
\text { five products }\end{array}$ \\
\hline Li-ion battery & $42 \%$ & $58 \%$ & $\begin{array}{l}\text { Results of questionnaire survey } \\
\text { in this study }\end{array}$ \\
\hline
\end{tabular}


Table 4. Results of the metal contained in the Li-ion batteries and referenced data $(\mathrm{mg} / \mathrm{kg})$

\begin{tabular}{|c|c|c|c|c|c|c|c|c|c|c|c|}
\hline & Samples & No. & $\mathrm{Li}$ & $\mathrm{Cr}$ & $\mathrm{Mn}$ & Co & $\mathrm{Ni}$ & $\mathrm{Cu}$ & $\mathrm{Zr}$ & $\mathrm{Au}$ & $\mathrm{Pb}$ \\
\hline & & $\overline{\mathrm{LL} 1}$ & 37,000 & 8.6 & 140 & 300,000 & 2,800 & 78,000 & 99 & $<1$ & 14 \\
\hline & & L2 & 36,000 & 11 & 70 & 45,000 & 250,000 & 82,000 & 11 & $<1$ & 34 \\
\hline & batteries for & L3 & 34,000 & 12 & 72 & 42,000 & 240,000 & 120,000 & 3.9 & $<1$ & 31 \\
\hline & & L4 & 31,000 & 2.2 & 3.0 & 260,000 & 880 & 250,000 & $<1$ & $<1$ & $<1$ \\
\hline & & LP1 & 19,000 & 8.4 & 1,200 & 160,000 & 27,000 & 87,000 & 8.9 & 70 & 1,500 \\
\hline & & LP2 & 50,000 & 24 & 4,100 & 430,000 & 22,000 & 230,000 & 11 & 30 & 2,300 \\
\hline & & LP3 & 20,000 & 20 & 2,000 & 170,000 & 30,000 & 85,000 & 2.3 & 52 & 940 \\
\hline & & LP4 & 25,000 & 7.3 & 790 & 200,000 & 18,000 & 120,000 & 56 & 87 & 190 \\
\hline & & LP5 & 31,000 & 16 & 570 & 260,000 & 8,400 & 120,000 & 52 & 110 & 120 \\
\hline & & LP6 & 24,000 & 14 & 830 & 200,000 & 57,000 & 93,000 & 3.9 & 57 & 410 \\
\hline & & LP7 & 24,000 & 16 & 1,500 & 200,000 & 11,000 & 47,000 & 3.1 & 110 & 700 \\
\hline & Li-ion & LP8 & 27,000 & 19 & 720 & 230,000 & 23,000 & 93,000 & 7.2 & 180 & 1,300 \\
\hline & batteries for & LP9 & 34,000 & 17 & 610 & 280,000 & 14,000 & 110,000 & 83 & 60 & 4.8 \\
\hline & cell phone & LP10 & 34,000 & 9.7 & 610 & 270,000 & 24,000 & 91,000 & 41 & 180 & $<1$ \\
\hline & & LP11 & 21,000 & 8.1 & 260 & 180,000 & 11,000 & 54,000 & 8.2 & 53 & 41 \\
\hline & & LP12 & 32,000 & 9.3 & 740 & 270,000 & 9,200 & 110,000 & 44 & 23 & 11 \\
\hline & & LP13 & 33,000 & 8.5 & 940 & 270,000 & 15,000 & 92,000 & 57 & 42 & 170 \\
\hline & & LP14 & 23,000 & 6.0 & 1,200 & 190,000 & 4,000 & 110,000 & 11 & 69 & 1,500 \\
\hline & & LP15 & 24,000 & 12 & 930 & 190,000 & 16,000 & 78,000 & 5.7 & 57 & 580 \\
\hline & & LP16 & 25,000 & 6.0 & 1,100 & 200,000 & 13,000 & 72,000 & 3.6 & 45 & 890 \\
\hline & & LP17 & 27,000 & 14 & 2,100 & 230,000 & 14,000 & 100,000 & 6.9 & 120 & 360 \\
\hline 4 & Oguchi et al [2 & & 17,000 & 0 & 3,800 & 170,000 & 0 & 140,000 & 0 & 0 & 0 \\
\hline $\mathscr{x}$ & Defra [21] & & 30,000 & - & 0 & 180,000 & 0 & - & - & - & 0 \\
\hline
\end{tabular}


Table 5. The ratio of final products which use Li-ion battery as batteries inside

\begin{tabular}{|l|r|}
\hline Video camera & $55 \%$ \\
\hline Digital camera & $58 \%$ \\
\hline Codeless electric implement & $22 \%$ \\
\hline
\end{tabular}

